\title{
Yaşlı Diyabetli Bireylerde Beslenme Tedavisi
}

\author{
Nutrition Therapy in Elderly People with Diabetes
}

\section{Meral Mercanlıgil ${ }^{1}$}

Geliş tarihi/Received: 30.08.2019 • Kabul tarihi/Accepted: 27.11.2019

\section{ÖZET}

Dünyada olduğu gibi ülkemizde de yaşlı nüfus artmaktadır. Yaşlı nüfusta diyabet görülme sıklığı yüksektir. Türkiye Diyabet Epidemiyolojisi Çalışması sonuçlarına (TURDEP2) göre 65 yaş üstü diyabetik hastalar tüm diyabetiklerin yaklaşık \%40’ını oluşturmaktadır. Diyabetli yaşlı bireylerde, güçsüzlük, hızlanmış kas kaybı, koroner kalp hastalığı, inme ve hipertansiyon gibi eşlik eden hastalıkların varlığı ve erken ölüm oranı, diyabetli olmayanlara göre daha yüksektir. Tedavinin temel taşı hasta veya hasta bakımından sorumlu kişinin eğitimidir. Hastalara öncelikle tıbbi beslenme tedavisi (TBT) ve yaşam tarzı değişiklikleri önerilir. Beslenme tedavisi planlanırken yaşa bağlı oluşan değişiklikler (diş kayıpları, tat ve kokuda değişiklik, gastrointestinal sistem değişikliğine bağlı emilim bozukluğu, çoklu ilaç kullanımı vb.) göz önüne alınmalıdır. Yaşlı diyabetlinin beslenme tedavisinde amaç; akut hiperglisemik komplikasyonların önlenmesi, hipogliseminin önlenmesi, kardiyovasküler komplikasyonlar, nefropati, nöropati gibi kronik komplikasyonların önlenmesi veya geciktirilmesi olmalıdır. Öncelik hipergliseminin semptom ve belirtilerinin ortadan kaldırılması, genel durumu ve bilinç düzeyi iyi olan yaşlıda normal yaşam beklentisinin sağlanmasıdır. Kırılgan yaşlılarda ise amaç akut metabolik komplikasyonları önlemektir. Yaşlı diyabetli bireyin beslenme durumu iyi değerlendirilmelidir. Obezitenin varlığı kadar malnütrisyonun varlığı da yaşlı diyabetli bireylerde sıklıkla görülmektedir. Yaşlı hastanın beslenme durumunu değerlendirmek için besin tüketim kaydı, vücut ağırlık değişimi, antropometrik ölçümler, laboratuvar verileri ve mini nütrisyonel değerlendirme (MNA) önemlidir.

Anahtar kelimeler: Yaşl, diyabet, trbbi beslenme tedavisi

\section{ABSTRACT}

As in the world, the elderly population is increasing in Turkey. The incidence of diabetes is high in the elderly population. According to Turkey Diabetes Epidemiology Study 2 (TURDEP 2), diabetic patients over 65 years of age constitute about $40 \%$ of all diabetic patients. The presence of concomitant diseases such as weakness, accelerated muscle loss, coronary heart disease, stroke and hypertension and the rate of early death are higher in elderly people with diabetes than those without diabetes. The cornerstone of treatment is the education of the patient or the person responsible for patient care. Firstly, medical nutrition therapy (TBT) and lifestyle changes are recommended to patients. Age-related changes (loss of teeth, changes in taste and odor, absorption disorders due to gastrointestinal system changes, use of multiple drugs, etc.) should be considered while planning nutritional therapy. The aims of nutrition treatment of elderly diabetic must be prevention of acute hyperglycemic complications, prevention of hypoglycemia, prevention or delay of chronic complications such as cardiovascular complications, nephropathy, neuropathy. The priority is to eliminate the signs and symptoms of hyperglycemia, to provide normal life expectancy in the elderly diabetic in good general condition and consciousness. In frail elderly, the aim is to prevent acute metabolic complications. Nutritional status of elderly people with diabetes should be

1. İletişim/Correspondence: Hacettepe Üniversitesi, İç Hastalıkları ABD. Endokrinoloji ve Metabolizma Bilim Dalı, Ankara, Türkiye

E-posta: mmercanligil@gmail.com • (1) https://orcid.org/0000-0001-9532-8516 
evaluated well. The presence of malnutrition as well as the presence of obesity is frequently seen in elderly diabetic patient. Food consumption record, body weight change, anthropometric measurements, laboratory data and mini nutritional assessment (MNA) are important to assess the nutritional status of the elderly diabetic.

Keywords: Elderly, diabetes mellitus, medical nutritional therapy

\section{GíRiş}

İnsan yaşamının ilerleyen dönemi yaşlılık olarak adlandırılır. Dünya Sağlık Örgütü (DSÖ), psikogeriatrik yaşlılık dönemini 65 yaş ve üstünü 'yaşlı', 85 yaş ve üzerini 'çok yaşlı' olarak tanımlamıştır. Gerontolojistler ise yaşlılığı 65-74 yaş arası 'genç yaşlı',75-84 arası 'ileri yaşlı' ve 85 yaş üstü ise 'çok ileri yaşlı’ olarak sınıflandırılmaktadır $(1,2)$.

Kronolojik yaşlanma ile birlikte, vücut bileşimi, kalp damar sistemi, böbrekler, sindirim sistemi, karaciğer, beyin, sinirler, akciğerler ve endokrin sistemde işlevsel olarak yetersizlikler ortaya çıkmaktadır. Diyabet, yaşlanan nüfus için önemli bir sağlık sorunudur. Altmış beş yaş üstü yetişkinlerin yaklaşık dörtte birinde diyabet ve yarısında da prediyabet görülmektedir (3).

Ülkemizde yapılmış olan Türkiye Diyabet Epidemiyolojisi Çalışması 1 (TURDEP 1) 2002 yılı verilerine göre bozulmuş glukoz tolerans prevalansı \%6.7 ve diyabet prevalansı \%7.2 iken, 2010 yılında düzenlenen TURDEP 2 çalışmasında Türk erişkin toplumunda diyabet sıklığının \%13.7’ye ulaştığı görülmüştür. $\mathrm{Bu}$ çalışmaya göre 65 yaş üstü diyabetli bireyler tüm diyabetlilerin yaklaşık \%40'ını oluşturmaktadır $(4,5)$.

Yaşlanma ile birlikte, şişmanlık, fiziksel aktivite yetersizliği, kas kütlesindeki azalma, diğer kronik hastalıkların varlığı, kullanılan ilaçlar ve genetik alt yapı yaşlıda insülin direncine neden olmaktadır. Yaşlanma ile oluşan insülin salınımındaki azalma, hepatik glukoz üretiminin inhibisyonundaki yetersizlik sonucu karaciğer glukoz üretiminde artış, insülin reseptörlerinde bozulma, leptin artışı, yaşlılardaki hipergliseminin patogenezinde rol oynayan diğer temel etmenlerdir. Yaşlılıkta kullanılan ilaçlar, adipozitede artış ve başka hastalıklar insülin salınımında azalmaya neden olur (6).
Diyabetli yaşlı bireylerde, güçsüzlük, hızlandırılmış kas kaybı, koroner kalp hastalığı, inme ve hipertansiyon gibi eşlik eden hastalıkların varlığı ve erken ölüm oranı, diyabetli olmayanlara göre daha yüksektir (3).

Diyabeti olan yaşlıların tedavisi; tıbbi beslenme tedavisi (TBT), egzersiz, insülin ve/veya oral antidiyabetik ilaçlardan oluşur. Tedavinin temel taşı hasta veya hasta bakımından sorumlu kişinin eğitimidir. Hastalara öncelikle TBT ve yaşam tarzı değişiklikleri önerilir (7). Bu derleme yazıda yaşlı diyabetli bireylerde, diyabet yönetimine etki eden yaşlılığa bağlı değişiklikler ve tıbbi beslenme tedavisinin ilkeleri irdelenecektir.

\section{Yaşlı Diyabetli Bireylerde Glisemik Kontrol Hedefleri}

Hedef belirlemede kronolojik yaşla birlikte yaşam beklentisi de önemlidir $(8,9)$.

1. Yaşam beklentisi $>15$ yll ve majör komorbidite yoksa HbA1c <\%7 (<53 mmol/mol)

2. Yaşam beklentisi 5-15 yll ve orta derecede komorbidite var ise $\mathrm{HbA} 1 \mathrm{c}<\% 7.5(<58 \mathrm{mmol} / \mathrm{mol})$

3. Yaşam beklentisi $<5$ yll ve majör komorbidite varsa HbA1c $<\% 8.5 \quad(<69 \mathrm{mmol} / \mathrm{mol})$ olarak hedeflenir $(8,9)$.

\section{Yaşla Birlikte Oluşan Değişiklikler}

Yaşa bağlı oluşan değişiklikler beslenme tedavisini etkileyeceğinden dolayı yaşlı diyabetlinin beslenme planı oluşturulurken bu değişiklikler göz önüne alınmalıdır. Bu değişiklikler şunlardır:

1. Diş kayıpları, duyarlı diş ve diş etleri besinlerin çiğnenmesini güçleştirir (10). 
2. Özofageal motilitede ve tükrük salınımındaki azalmadan dolayı yutma güçlüğü oluşur. Tükrük salınımındaki azalma, nişastanın sindirimini azaltır (11).

3. Gastrointestinal sistemdeki değişikler: Hidroklorik asit, pepsin ve gastrik müköz salgıda yaşa bağlı azalma, kalsiyum, demir, B12 vitamini gibi bazı besin ögelerinde yetersiz sindirim ve emilim söz konusu olur. Yaşlanma ile ince bağırsaklardan emilim azalır. Konstipasyon yaşlılarda kronik ve yaygin bir sorundur $(11,12)$.

4. Renal fonksiyonlardaki değişiklikler: Yaşlanma ile nefronların sayısı, total kan akımı, glomerüler filtrasyon hızı (GFH), idrar kreatin atımı, renal konsantrasyon yeteneği azalır. Diyet ile alınan sodyumun ve proteinin tutulumu etkilenir (12).

5. Sinir sisteminde oluşan değişiklikler: Yaşlılarda görülen demans ve Alzheimer hastalığı, yemek yemeği unutma nedeniyle malnütrisyon riskini artırır. Diyabetli olma süresi arttıkça bilişsel fonksiyon düşer. Ancak hipoglisemik tedavi ile, HbA1c düzeyi azalır ve bilişsel fonksiyon düzelir. Diğer sinir sistemi değişiklikleri; tat, koku, görme ve işitme kayıplarıdır (13).

6. İmmün sistemdeki değişiklikler: Yaşlanma ile immün sistem fonksiyonları azalır. Protein ve çinkonun alınması yara iyileşmesini kolaylaştırır (14).

7. Çoklu ilaç (polifarmasi) kullanımı: Altmış beş yaş ve üzerinde olan bireylerin \%80-86'sında bir veya birden çok kronik hastalıkların (kardiyovasküler hastalıklar, hipertansiyon gibi) varlığı ve buna bağlı ilaç kullanımı, iştahsızlık, bulantı, ishal gibi yan etkilerden dolayı beslenmeyi olumsuz etkileyebilir (14).

\section{Yaşlı Diyabetli Bireylerde Tıbbi Beslenme Tedavisi}

Beslenme tedavisinin amaçları; akut hiperglisemik komplikasyonların önlenmesi, hipogliseminin önlenmesi, kardiyovasküler komplikasyonların önlenmesi, nefropati, nöropati gibi kronik komplikasyonların önlenmesi veya geciktirilmesi olmalıdır. Öncelik hipergliseminin semptom ve belirtilerinin ortadan kaldırılmasıyla genel durumu ve bilinç düzeyi iyi olan yaşlıda normal yaşam beklentisinin sağlanmasıdır (15). Kırılgan yaşlılarda ise amaç akut metabolik komplikasyonların önlenmesidir. Kırılganlık, yaşın artmasıyla birlikte çoklu vücut sistemlerinin zaman zaman yerleşik rezervlerini kaybedebileceği, bunun çevresel strese dayanma kapasitelerini azaltabileceği bir durumdur (16). Kurılgan yaşlılar, fiziksel, zihinsel, psikolojik ve/veya sosyal kısıtlamalar ve tekrarlayan hastalık nedeniyle günlük yaşam aktivitelerinde sınırlıdır (17).

Obezitenin varlığı kadar malnütrisyon da yaşlı diyabetli bireyde sıklıkla görülmektedir. Yaşlı hastanın beslenme durumu için besin tüketim kaydı, vücut ağırlık değişimi, antropometrik ölçümler ve laboratuvar verileri iyi değerlendirilmelidir $(12,18)$. Mini nütrisyonel değerlendirme (MNA) de beslenme durum değerlendirmesi için kullanılan yöntemlerden biri olabilir (9).

Yaşlanmayla birlikte; fizyolojik değişiklikler (gastrointestinal disfonksiyon, tat ve koku almada değişiklik, nörolojik hastalıklar vb.), yalnızlık, yemek pişirme ve beslenme hakkında bilgi eksikliği, yiyecek alışverişi yapamamak ve/veya hazırlayamamak gibi sosyal nedenlerden, bunama, depresyon, konfüzyon, anksiyete gibi psikolojik nedenlerden dolayı malnütrisyon görülebilir (19-21). Uzun dönem bakım evlerinde kalan yaşlı diyabetli bireyler düşük vücut ağırlığında olmaya yatkındır. Ayrıca, yetersiz beslenme durumu; artmış morbidite ve mortaliteyle bağlantılıdır. Malnütrisyonun önlenmesi ve tedavisi, erken beslenme desteği azalmış mortalite ile ilişkilidir (9). Bu durumda, enteral veya gastrointestinal yolun kullanılamadığı ya da hastalık durumuna göre besin ihtiyacının karşılanamadığı durumlarda parenteral beslenme desteğinin endikasyonu vardır (17).

Yaşam tarzı değişikliği, kan glukoz kontrolünün yararlarının ötesinde ilaç dışı tedavi malnütrisyonun, sarkopeninin ve fonksiyonel bozulmanın önlenmesi için elzemdir. Yaşlı diyabetiklere verilen beslenme 
önerisi, uygun bir beslenme durumunu sağlamayı hedeflemektedir. Tip 2 diyabetli bireylerin tedavisinde yaşam tarzı değişikliği tedavinin köşe taşıdır. Hastalarin ortalama \%30'u sadece TBT ve egzersiz ile tedavi edilmektedir. Farmakolojik tedavi alan diyabetli bireylerde TBT ve egzersiz, kardiyovasküler risk faktörleri üzerine yararlı bir etki sağlayacak kadar iyi bir glisemik kontrolün başarılmasına yardım eder (9).

Enerji Gereksinimi: Yağsız kas kütlesi 30 yaşlarında vücut ağırlığının \%45’i iken, 70 yaşlarında \%27’ye düşer. İskelet kası, düz kas ve vücut organları bu düşüşten etkilenir. Yağ kütlesi ise 30 yaşlarında vücut ağırlığının \%14’ü iken, 70 yaşlarında \%30’a yükselir. Toplam vücut suyu da yaşın ilerlemesi ile beraber düşerek yağsız vücut kütlesi kaybına eşlik eder (14).

Yaşlllar için beslenmede en belirgin değişiklik enerji gereksiniminin azalmasıdır. Yaşlı diyabetli bireylerin enerji gereksinimleri, benzer vücut ağırlığında ve daha genç olan bireylerden \%20 daha azdır (14). Bu hem enerji harcamasinın azalmasina hem de kas kütlesinin azalmasına (sarkopeniye) bağlıdır. Kas kütlesindeki azalma, fiziksel aktivitenin azalması ile ilişkili olabilir. Azalmış aktifmetabolik kütleyle birlikte bazal enerji harcamasının azalması nedeniyle daha az enerjiye gereksinim duyulur. Erişkinlerin toplam enerji harcamalarında (TEE) yaşamları boyunca yaklaşık \%20'lik düşüş olduğu, fiziksel aktivite hayat boyunca sürdürülürse TEE’nin de düşmeden aynı seviyelerde kaldığı gösterilmiştir (22).

Karbonhidratlar: Yaşlı diyabetli bireyler için ideal olan karbonhidrat tüketim miktarına yönelik kanıtlar yetersizdir. Diyabetli bireyle işbirliği içinde hedefler geliştirilmelidir. Tüketilen karbonhidrat miktarı ve insülin dozu öğünden sonra kan glukoz düzeylerini etkileyen en önemli faktörlerdir ve öğün planının geliştirilmesinde göz önüne alınmalıdır $(3,18)$. Sadece TBT alan veya TBT ile birlikte oral antidiyabetik (OAD) veya insulin kullanan bireylerde karbonhidrat alımı öğün ve ara öğünlere bireye özgü olarak dağıtılmall, günden güne değişmemeli ve benzer miktarlarda olmalıdır. Yaşlı diyabetli bireylerin beslenmesinde; sebzeler, meyveler, tam taneli tahillar, kurubaklagiller ve düşük yağlı süt ve süt ürünlerinden karbonhidrat alımı önerilmektedir. (18).

Proteinler: Yaşlanma ile birlikte yetersiz protein alımı, insülin direnci, proteinlerin anabolik direnci, hareketsizlik nedenleri ile mevcut proteini kullanma yeteneğinde azalma olmaktadır. Aynı zamanda proteinlerin oksidatif modifikasyonu nedeniyle artan protein ihtiyacı işlevsellik kaybına yol açar (23). Yaşlı diyabetlilerde yetersiz beslenme, özellikle de yetersiz protein alımı, sarkopeniyi ve kırılganlığı artırabilir. Bunun önlenmesi yaşlı diyabetlinin ihtiyacı olan yeterli beslenmenin (özellikle proteinin) sağlanması, aerobik ve direnç egzersizi ile mümkün olabilir (24,25).

Yaşlı diyabetli bireylerde; GFH, mikroalbumin varlığı ve/veya kardiyovasküler hastalık (KVH) gibi eşlik eden başka hastalık durumu değerlendirilerek, 1.0-1.6 g/kg/ gün veya öğünde 25-30 g olacak şekilde yüksek kaliteli protein alımını savunan öneriler vardır $(26,27)$.

Yağlar: KVH riskini azaltmada düşük kolesterollü ve düşük doymuş yağlı diyetler önerilirken, malnütrisyon riski de düşünülmelidir (9). Yaşlı diyabetlinin beslenme tedavisinde toplam enerjinin $<\% 30$ 'u yağlardan sağlanmalıdır (18). Doymuş yağlar toplam enerjinin $<\% 10$ 'u olmalıdır. Dislipidemisi olan yaşlılarda bu oran <\%7 olmalıdır. Kolesterol <200$300 \mathrm{mg} /$ gün arasında bireysel değişiklik gösterebilir. $\mathrm{Bu}$ nedenle yaşlı diyabetlilerin haftada 2-3 kez balık yemeleri önerilmektedir (18).

Mikro besin ögeleri: Yaşlı diyabetlilerde hiperglisemi artan oksitatif stres ile birliktedir. Küçük ölçekli çalışmalar, antioksidant vitamin (C ve $\mathrm{E}$ vitaminleri) eklemelerinin glisemik kontrolü sağlayabileceğini göstermiştir. Ancak uzun dönemde güvenlik açısından kanıt yetersizliği nedeniyle; E vitamini, C vitamini, karoten gibi antioksidanların suplemantasyonu önerilmemektedir $\quad(3,18)$. B12 vitamini yetersizliği, yaşlı popülasyonun \%20'den fazlasında görülmektedir. Yetersizliğin \%60'ının malabsorbsiyon kaynaklı olduğu bilinmektedir (28). Magnezyum ve çinko eklemeleri glisemik kontrolde 
düzelmeleri sağlayabilir. Ayrıca, düşük enerji alan yaşlı diyabetiklerde günlük multivitamin takviyesi uygun olabilir (18). Yaşlı diyabetliler için TBT algoritması Şekil 1'de gösterilmiştir (18).

Hipoglisemi: Yaşlı diyabetlilerde hipoglisemi riski genç yetişkinlerden daha sık karşılaşılan önemli bir sorundur. Fonksiyonel kayıp, hipogliseminin hılı tanımlanmasını ve uygun tedaviyi güçleştirebilir. Hipoglisemiye bağlı düşmeler, kırık riskini de artırmaktadır. Nöbetler, koma vekognitifdisfonksiyon, kardiyak sorunlara neden olabilir. Yaşlının ve bakımından sorumlu olan kişilerin hipoglisemi konusunda eğitilmesi önemlidir (29). Hipogliseminin nedenleri olarak; ileri yaş, polifarmasi, yakın dönemde hastaneye yatış, kognitif fonksiyon bozukluğu, kontregülatör hormon salınımında yetersizlik, az ve/ veya düzensiz beslenme, alkol, sedatif ilaç kullanımı, böbrek yetmezliği sayılabilir (29).

\section{Yaşlı Diyabetliler için TBT Algoritması}

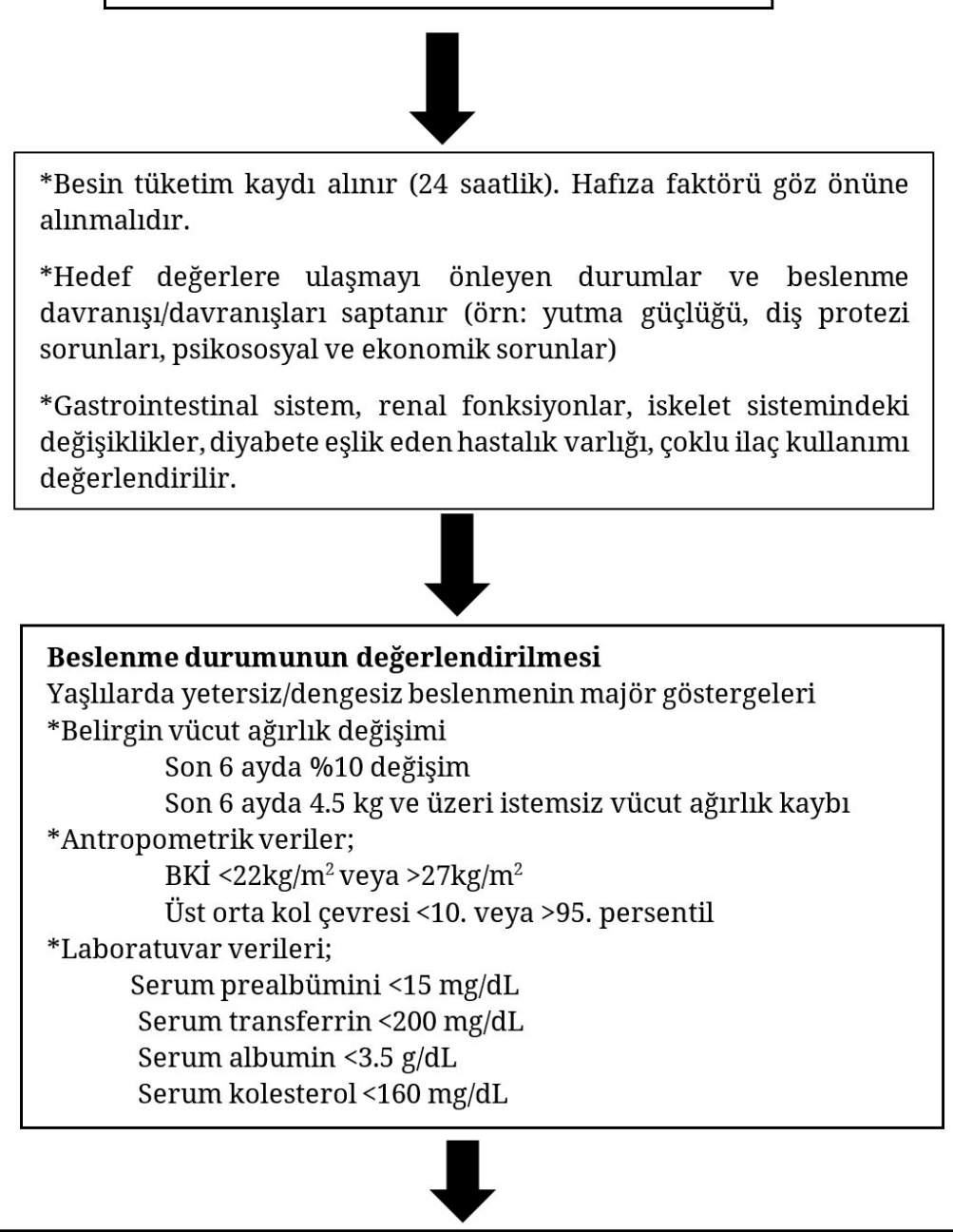

Saptanan sorunlara çözüm yolları geliştirilir.

- Tedavi hedeflerine ulaşmayı önleyen sağlıksız beslenme davranışlarının tedavi üzerindeki etkileri ile ilişkili açıklama yapılır.

- Hipoglisemiye sebep vermeyen KH alımını sağlamanın önemi vurgulanır.(Hipoglisemiyi

fark etmeme riski göz önüne alınmalı).

- Besin kısıtlaması yerine medikal tedavi ile kan glukoz kontrolünün sağlanması tercih edilebilir. 


\section{SONUÇ VE ÖNERILLER}

Yaşlı nüfus dünyada olduğu gibi ülkemizde de artmaktadır. Kronik bir hastalık olan diyabet ise yaşlı grupta en sık görülen hastalıklardandır. Diyabetli yaşlının beslenme tedavisi planlanırken, yaşlının temel ihtiyaçlarının karşılanması, komplikasyonların önlenmesi temel amaçken yaşa bağlı oluşan birçok fizyolojik değişiklik, eşlik eden hastalıklar ve aldığı medikal tedavi gözden kaçırılmamalıdır. Yine beslenme tedavisi planlanırken yaşlı diyabetli bireyin (özellikle bakım evlerinde yaşayan yaşlıların) malnütrisyon riski açısından değerlendirilmesi, yaşlı ve yaşlının bakımından sorumlu olan kişilerin hipoglisemi konusunda bilgilendirilmesi gerekmektedir. Yaşlı diyabetlilerin beslenme tedavisi planlandıktan sonra en az yılda bir kez diyetisyen kontrolü sağlanmalıdır.

Çıkar çatışması - Conflict of interest: Yazarlar çıkar çatışması olmadığını beyan ederler. - The authors declare that they have no conflict of interest.

\section{KAYNAKLAR}

4. WHO Psychogeriatric, Report of a WHO Scientific Group, Technical Reports Series 507, 1972. Geneva. Cited in Davise AM. Epidemiology. 1972;185:14(1):9-21.

5. WHO. The uses of epidemiology in the study of the elderly. WHO, Technical Reports Series; 1984. p.8-9.

6. American Diabetes Association Older Adults: Standards of Medical Care in Diabetes-2019. Diabetes Care. 2019;42(Suppl.1):S139-S47.

7. Satman I, Yllmaz T, Şengül A, Salman S, Salman F, Uygur S, et al. Population-Based Study of Diabetes and Risk Characteristics in Turkey: results of the Turkish Diabetes Epidemiology Study (TURDEP). Diabetes Care. 2002;25(9):1551-6.

8. Türkiye Endokrinoloji ve Metabolizma Derneği (TEMD). Yaşlılıkta Endokrinolojik Hastalıklar Tedavi Kılavuzu, Miki Matbaacılık San. ve Tic. Ltd. Şti. :Ankara; 2019.s.140.

9. Chang A, Halter JB. Aging and insülin secretion. Am J Physiol Endocrinol Metab. 2003;284:E7-E12.

10. Meneilly GS. Diabetes in the elderly. Med Clin North Am. 2006;90(5):909-23.

11. Türkiye Endokrinoloji ve Metabolizma Derneği (TEMD): Diabetes Mellitus ve Komplikasyonlarının Tanı, Tedavi ve İzlem Kılavuzu, 11. Baskı. Ankara: Miki Matbaacılık
San. ve Tic. Ltd. Şti.; 2018, s.257.

12. Kirkman S, Briscoe VJ, Clark N, Florez H, Haas LB, Halter JB, et al. Diabetes in older adult. Diabetes Care. 2012; 35(12):2650-64.

13. Niedert KC, Dorner B. Nutrition Care of the Older Adult. 2nd Ed. Chicago, American Dietetic Association. 2004. p.323

14. Mc Laughlin S. Potters MA, editor. Handbook of Diabetes Medical Nutrition Therapy. ASPEN Publishers Inc. Gaithersburg, Maryland; 1996. 527 p.

15. Denic A, Glassock RJ, Rule AD. Structural and functional changes with the aging kidney. Adv Chronic Kidney Dis. 2016;23(1):19-28.

16. Yaffe K, Falvey C, Hamilton N, Schwartz AV, Simonsick EM, Satterfield S, et al. Diabetes, glucose control and 9-year cognitive decline among older adults without dementia. Arch Neurol. 2012;69:1170-5.

17. Franz MJ, Bantle JP, Beebe CA, Brunzell JD, Chiasson JL, Garg A. Evidence-based nutrition principles and recommendations for the treatment and preventions of diabetes and related complications. Diabetes Care. 2002;25(1):148-98.

18. Anon. Guidelines for improving the care of the older person with diabetes mellitus. JAGS. 2003;51(5):S265-S80.

19. Clegg A, Young J, Iliffe S, Rikkert MO, Rockwood K. Frailty in elderly people. Lancet. 2013;381:752-62

20. Volkert D, Berner YN, Berry E, Cederholm T, Coti Bertrand P, Milne A, et al. DGEM (German Society for Nutritional Medicine), Lenzen-Grossimlinghaus R, Krys U, Pirlich M, Herbst B, Schütz T, Schröer W, Weinrebe W, Ockenga J, Lochs H; ESPEN (European Society for Parenteral and Enteral Nutrition). ESPEN Guidelines on Enteral Nutrition: Geriatrics. Clin Nutr. 2006;25:330-60.

21. Diyabet Diyetisyenleri Derneği. Diyabetin Önlenmesi ve Tedavisinde Kanita Dayalı Beslenme Tedavisi Rehberi, İstanbul, Armoni Nüans Baskı Sanatları AŞ, 2019. s. 80

22. Hickson M. Malnutrition and ageing. Postgrad Med J. 2006;82:2-8.

23. Saunders J, Smith T, Stroud M. Malnutrition and undernutrition. Medicine. 2011;39:45-50.

24. Brownie S. Why are elderly individuals at risk of nutritional deficiency? Intern J Nurs Pract. 2006;12:1108.

25. Johnston RE, Chernoff R. Contemporary Nutrition Support Practice. Matarese LE, Gottschlich MM, editors. Geriatrics. 2nd ed. Philadelphia, PA: Saunders; 2003, 376-383 p.

26. American Diabetes Association. Lifestyle management: Standards of medical care in diabetes-2018. Diabetes 
Care. 2018;41(Suppl. 1):S38-S50.

27. Sinclair AJ, Abdelhafiz A, Dunning T, Izquierdo M, Rodriguez Manas L, Bourdel-Marchasson I, et al. An international position statement on the management of frailty in diabetes mellitus: summary of recommendations 2017. J Frailty Aging. 2018;7:10-20.

28. Castro-Rodríguez M, Carnicero JA, Garcia-Garcia FJ, Walter S, Morley JE, Rodríguez-Artalejo F, et al. Frailty as a major factor in the increased risk of death and disability in older people with diabetes. J Am Med Dir Assoc. 2016;17:949-55.

29. Bauer J, Biolo G, Cederholm T, Cesari M, Cruz-Jentoft AJ, Morley JE, et al. Evidence-based recommendations for optimal dietary protein intake in older people: a position paper from the PROT-AGE Study Group. J Am Med Dir Assoc. 2013;14(8):542-59.

30. Academy of Nutrition and Dietetics, Food and nutrition for older adults: promoting health and wellness. J Acad Nutr Diet. 2012;112:1255-77.

31. Andrès E, Loukili NH, Noel E, Kaltenbach G, Abdelgheni MB, Perrin AE, et al. Vitamin B12 (cobalamin) deficiency in elderly patients. CMAJ. 2004;171(3):251-9.

32. Sircar M, Bhatia A, Munshi M. Review of hypoglycemia in the older adult: Clinical implications and management. Can J Diabetes. 2016;40(1):66-72. 